\title{
Light wavelength-dependent $E$. coli survival changes after simulated solar disinfection of secondary effluent
}

\section{Stefanos Giannakis ${ }^{1,2,3}$, Sami Rtimi ${ }^{3}$, Efthymios Darakas ${ }^{1}$, Antoni Escalas-Cañellas ${ }^{2,4}$, César Pulgarin ${ }^{3, *}$}

${ }^{1}$ Laboratory of Environmental Engineering and Planning, Department of Civil Engineering, Aristotle University of Thessaloniki, 54124 Thessaloniki, Greece

${ }^{2}$ Laboratory of Control of Environmental Contamination, Institute of Textile Research and Industrial Cooperation of Terrassa (INTEXTER), Universitat Politècnica de Catalunya, Colom 15, 08222 Terrassa, Catalonia, Spain

${ }^{3}$ Swiss Federal Institute of Technology, Lausanne, Institute of Chemical Sciences and Engineering, 1015 Lausanne, Switzerland

${ }^{4}$ Department of Chemical Engineering \& Terrassa School of Engineering, Universitat Politècnica de Catalunya, Colom 1, 08222, Terrassa, Catalonia, Spain

*Corresponding author: César Pulgarin, Tel: +41216934720; Fax: +41216936161; E-mail: cesar.pulgarin@epfl.ch

\section{Abstract}

In this study, the photoreactivation and the modification of dark repair of E. coli in a simulated secondary effluent were investigated after initial irradiation in different conditions. The simulated solar exposure of the secondary wastewater was followed by exposure to six different low-intensity fluorescent lamps (blacklight blue, actinic blacklight, blue, green, yellow and indoor light) up to $8 \mathrm{~h}$. When phoreactivation was monitored, blue and green color fluorescent light led to an increased bacterial regrowth. Blacklight lamps further inactivated the remaining bacteria, while yellow and indoor light led to an accelerated growth of healthy cells. Exposure to fluorescent lamps was followed by long term dark storage, to monitor the bacterial repair in the dark. The response was correlated with the pre-exposure dose of applied solar irradiation and at a lesser extent with the fluorescent light dose. Bacteria which have undergone extensive exposure had no response neither under fluorescent light nor during dark storage. Finally, the statistical treatment of the data allowed to suggest a linear model, non-selective in terms of the fluorescent light applied. The estimation of the final bacterial population was well predicted (R-sq 75\%) and the photoreactivation risk was found more important cultivable cells. 
During the last decades, chlorination has been gradually replaced with ozone or ultraviolet light for wastewater disinfection ${ }^{1}$. The use of UVC-based Advanced Oxidation Processes for decontamination ${ }^{2}$ and disinfection ${ }^{3}$ of secondary wastewater is gaining more interest, supported by results which demonstrate their efficiency. However, the main disadvantage of UV-C light applications is the lack of residual action after the completion of the disinfection treatment, compared to the action of residual chlorine in treated water ${ }^{3,4}$, harboring the danger of bacterial regrowth.

The repair of the UV-induced DNA damage, namely cis-syncyclobutane pyrimidine dimers (CPDs) ${ }^{5}$ that leads to reactivation of the microorganisms is demonstrated by various methods that include photoreactivation (light-mediated repair) and dark repair (DR) mechanisms (e.g. nucleotide and base excision repair). Nucleotide excision repair, is a process taking place in absence of light, while photoreactivation (PHR) starts with the post-irradiation exposure to light. The two bacterial mechanisms developed over time mostly share the final outcome practically, being the re-contamination of the sample. Photoreactivation is the enzymatic process, attributed to photolyase, which utilizes a relatively broad spectrum of light in order to recover the bacterial activity and repair the thymine dimers induced in the DNA strands ${ }^{6,7,8}$. The dark repair process is a multi-enzyme mechanism that excises and repairs the damaged DNA segments ${ }^{8}$.

Solar light is composed out of UVB, UVA, visible and infrared (IR) wavelengths. The different wavelengths withhold a disinfecting capability; in summary, UVB is known to directly cause photoproducts ${ }^{5}$, such as cyclobutane pyrimidine dimers, pyrimidine (6-4) pyrimidine dimers, photoproducts of purine bases, and more ${ }^{9}$ and indirectly induce reactive oxygen species (ROS) ${ }^{10}$ that attack nucleic acid, proteins and cell lipids ${ }^{11}$, UVA and near-UV visible denaturize cell's proteins ${ }^{12}$ or cause ATP disruption ${ }^{13}$ etc., while IR heats water, causing a synergy with $\mathrm{UV}^{14}$ or directly degrades cell components ${ }^{15}$. In summary, bacterial damage is attributed to both dimerization and both internal and external ROS action. Solar disinfection of drinking water ${ }^{16}$ offered a very practical and relatively successful method of water treatment for developing countries, unable to afford UVC treatment methods.

However, there are some considerations since UVB can attack bacterial DNA causing dimerization ${ }^{17}$, the specific damage on the DNA strands can be repaired, employing either of the two repair modes. The most feasible solar wastewater application ${ }^{18}$, the stabilization ponds, receives the influent, subjects it to sunlight, thus causing disinfection. When bacteria get inactivated, according to the time of the day, they are either present in prolonged milder solar exposure mode or in dark conditions. Also, the difference in latitude and azimuth angles can also lead to skewing of light; each situation 
could induce a different regrowth response. Especially towards the end of the exposure periods (and no longer effectively inactivating bacteria), which are considered to overpass the photoreactivating dose $^{19}$, these conditions could pose a critical timeframe for bacterial population recovery.

There is a noticeable gap in the literature on the regrowth potentials of solar treated bacteria, especially the ones present in wastewater. The majority of the works studying PHR and/or DR focus on the post-irradiation events of UVC treatment, assessing issues of quantification ${ }^{20}$, standardization $^{19}$, modeling ${ }^{7,21}$, pre-UV treatment conditions ${ }^{22}$, UV treatment conditions ${ }^{23}$ and postirradiation handling ${ }^{24}$. Only a few works focus on the study of bacterial dark repair after photolytic disinfection of wastewater ${ }^{25,26,27}$. Also, PHR in general is known to demonstrate faster and in higher extent than DR and there are no works about PHR after solar disinfection of wastewater. However, there are indications, in UVC experiments, indicating that visible light can reactivate bacteria ${ }^{19}$ and more specifically, photolyase is activated by blue/near UV wavelength ${ }^{28}$.

This work focuses on the photolytic disinfection of secondary wastewater and the bacterial regrowth risks after its completion either by photoreactivation or dark repair. A series of tests has been conceived in order to assess the PHR and DR risks, after simulating solar exposure of E. coli-spiked synthetic secondary effluent; the composition of the wastewater is simulating the real secondary effluent that has undergone primary and biological (secondary) treatment. Photoreactivation was intensely studied, aiming to attribute the bacterial recovery in specific wavelength bands, by the use of six different fluorescent colored lamps, and relate the applied energy, by varying its wavelength, with the final bacterial population. The effect of specific wavelengths on bacterial post-treatment kinetics is addressed. Finally, the ability to alter the normal DR potential by the pre-illumination tests and is also under study, in search of a correlation between enhanced or reduced dark repair at certain wavelengths. 


\section{Materials and Methods}

\subsection{Synthetic secondary effluent preparation}

The preparation of the synthetic wastewater was made by dissolving $160 \mathrm{mg} / \mathrm{L}$ peptone, $110 \mathrm{mg} / \mathrm{L}$ meat extract, $30 \mathrm{mg} / \mathrm{L}$ urea, $28 \mathrm{mg} / \mathrm{L} \mathrm{K}_{2} \mathrm{HPO}_{4}, 7 \mathrm{mg} / \mathrm{L} \mathrm{NaCl}, 4 \mathrm{mg} / \mathrm{L} \mathrm{CaCl}_{2} \cdot 2 \mathrm{H}_{2} \mathrm{O}$ and $2 \mathrm{mg} / \mathrm{L}$ $\mathrm{MgSO}_{4} \cdot 7 \mathrm{H}_{2} \mathrm{O}$ in distilled water, as shown in table 1 and instructed by OECD ${ }^{29}$. The COD of the solution was around $250 \mathrm{mg} / \mathrm{L}$. In order to better approximate the values of secondary effluent, a 10\% dilution was used. $1 \mathrm{~mL}$ of concentrated $\left(10^{9}\right)$ bacterial solution per liter was added in the solution, to reach an initial population of $10^{6} \mathrm{CFU} / \mathrm{mL}$. The transmittance levels approach the one of secondary effluent.

Although the E. coli as a fecal indicator bacterium has been questioned ${ }^{30,31}$, there are strong facts supporting its use in such studies ${ }^{32}$. More specifically, in this work the E. coli K-12 strain was used; K-12 approximates well the Gram-negative wild type ${ }^{33}$. The bacterial E. coli K-12 strain (MG 1655) was acquired from "Deutsche Sammlung von Mikroorganismen und Zellkulturen”. Preparation of the bacterial cultures, the growth and inoculation, as well as the spiking of the synthetic effluent was performed as described analytically in our previous works ${ }^{27,34}$. The initial bacterial concentration in all experiments was $10^{6} \mathrm{CFU} / \mathrm{mL}$.

\subsection{Reagents and Reactors}

Chemicals were acquired from the following suppliers: Peptone from $\mathrm{I}^{2} \mathrm{CNS}$, Switzerland, meat extract, $\mathrm{NaCl}, \mathrm{CaCl}_{2} \cdot 2 \mathrm{H}_{2} \mathrm{O}, \mathrm{MgSO}_{4} \cdot 7 \mathrm{H}_{2} \mathrm{O}$ from Fluka, France, urea from ABCR GmbH, Germany and $\mathrm{K}_{2} \mathrm{HPO}_{4}$ from Sigma-Aldrich, Germany.

The reactors used for the two experimental parts, solar irradiation and post-irradiation events, were from UV-transparent Pyrex glass, 65-mL batch reactors. $50 \mathrm{~mL}$ of wastewater were first illuminated under simulated solar irradiation, followed by exposure to monochromatic or polychromatic lamps for 2-8 $\mathrm{h}$ and finally were kept for $48 \mathrm{~h}$ in the dark; more details are given in the next sections. All experimental parts took place under mild stirring with a magnetic bar (250 rpm).

\subsection{Sampling and bacterial enumeration}


Samples were drawn as follows: semi-hourly sampling took place for the solar exposure part, and at 2, 4 and $8 \mathrm{~h}$ for the exposure under fluorescent light part, respectively. In order to assess the dark events, daily sampling was performed to determine the viable counts. Every sample was approximately $1 \mathrm{~mL}$, drawn in sterile Eppendorf sealable caps. Spread plating technique on non-selective plate count agar (PCA) was applied for the cultivation of the bacteria, in 9-cm sterile plastic Petri dishes. All experiments were performed in duplicates, while plating three consequent dilutions.

\subsection{Solar simulator and fluorescent lamps}

The light source was a bench-scale Suntest CPS solar simulator from Hanau, employing a $1500 \mathrm{~W}$ aircooled Xenon lamp (model: NXe 1500B). 0.5\% of the emitted photons are emitted within a range shorter than $320 \mathrm{~nm}$ (UVB) and 5-7\% in the UVA area (320-400 nm). After $400 \mathrm{~nm}$, the emission spectrum follows the visible light spectrum. The solar simulator also contains an uncoated quartz glass light tube and cut-off filters for UVC and IR wavelengths. The intensity levels employed were monitored by a pyranometer and UV radiometer (Kipp \& Zonen, Netherlands, Models: CM6b and CUV3). Measurements took place at the beginning of each experiment to ensure the desired emission levels, and lamps are changed every $1500 \mathrm{~h}$, in all different Suntest apparatus used in the research period.

The monochromatic lamps (18 W blacklight blue, actinic blacklight, blue, green and yellow) were acquired from Philips, while the visible light lamps were purchased from Osram. Their specifications are given in Table 2. Figure 1 presents the chromaticity diagram, explaining the color designation found on the $\mathrm{X}$ and $\mathrm{Y}$ coordinates of the lamps in Table 2, as well as the emission spectra of the fluorescent lamps. An apparatus bearing 5 lamps of $18 \mathrm{~W}$ nominal electrical value was used, and samples were placed $15 \mathrm{~cm}$ away from the light source. Eventually, less than $80 \mathrm{~W} / \mathrm{m}^{2}$ of global irradiation was reaching the body of the sample.

Finally, temperature was monitored and never exceeded $40^{\circ} \mathrm{C}$ during simulated solar tests and remained at room temperature for the fluorescent lamp tests.

\subsection{Experimental Planning}

The experimental sequence took place as follows. Phase 1: solar disinfection, Phase 2: exposure to light from the fluorescent lamps and Phase 3: dark storage. The simulated solar disinfection part (Phase 1) consisted of $0-4 \mathrm{~h}$ of illumination, whose progress was monitored by semi-hourly 
157 measurements of the bacterial population. Each sample was exposed to 4 different conditions, namely 1582 2, 4, or $8 \mathrm{~h}$ of exposure under fluorescent light (followed by dark storage), or directly dark storage as 159 a blank experiment (Phase 2). During this period, samples were plated at 2, 4 and $8 \mathrm{~h}$ to monitor the 160 bacterial population during the process. Finally, in order to assess the dark repair events taking place 161 in the bacteria, the samples were kept in the dark for $48 \mathrm{~h}$ after the completion of the irradiation 162 periods. More specifically, every $30 \mathrm{~min}$, a solar irradiated or a sample exposed in fluorescent light 163 was drawn and kept in the dark, and the corresponding population was measured every $24 \mathrm{~h}$ for $48 \mathrm{~h}$. 164 A schematic representation is given in the Supplementary Material (Figure S1). There were two sets 165 of experiments under the same conditions, for comparison and verification of the findings. Control 166 experiments included non-irradiated samples (no Phase 1) and irradiated samples that were not 167 exposed under fluorescent light (no Phase 2). 


\subsection{Solar disinfection experiments followed by exposure under fluorescent light}

Figure 2 presents the results of the post-illumination exposure of the bacterial samples to blacklight (BL) blue and actinic blacklight wavelengths. The Figures 2-i to 2-iv show the bacterial kinetics, after exposure to solar light, ranging from $0 \mathrm{~h}$ to $3 \mathrm{~h}$, respectively. Sampling was made semi-hourly; for reasons of clarity and simplification, no inbetween samples are presented; the events are presented in 4 distinct phases of solar treatment, such as untreated $(0 \mathrm{~h})$, mildly treated (1 \& 2 h) and heavily damaged (3 h of exposure. In the case of 4-h exposure to solar light, total disinfection was reached (the bacterial count was below the detection limit or undetectable by the spread plate technique), stable through all the subsequent treatment and efforts to photo-reactivate bacteria. Hence, these results are not shown. Between BL blue and actinic BL, the difference between the two lamps lies in the wavelength distribution: in the actinic BL lamp, there is an extra narrow wavelength emitted at $405 \mathrm{~nm}$, not present in the BL blue one, which falls closer to the side of UV that causes ROS production and therefore, additional peripheral damage to the cell ${ }^{35}$.

Figure 2-i presents the effect 2, 4 or $8 \mathrm{~h}$ of exposure to BL blue and actinic BL have on bacterial survival, on previously untreated sample. The samples untreated and not submitted to PHR light (dark control) show a slight growth (in logarithmic terms), nearly doubling its population in 8 hours. Free of solar-light damage and kept in the dark, unharmed and in a favorable medium, the bacteria grow, as it is observed. Two hours of exposure in the BL lamps do not modify greatly the bacterial population and have a rather mild inactivating effect 24 and $48 \mathrm{~h}$ after the treatment, in dark storage. This effect is enhanced by 4-h exposure time; there is a slight inactivation (in logarithmic terms) and a significant $90 \%$ decrease of the bacterial numbers in long times. However, $8 \mathrm{~h}$ of exposure under the same lights directly decreases bacterial viability. The employed wavelengths fall into the UV region, damaging the cell constituents, with the low intensity being the limiting step; 2 or 4 hours of illumination are not enough to impact directly the population. The cells are damaged by the energy accumulated in 8 hours.

Pre-illumination of the samples before their exposure to BL blue and actinic BL light, greatly modifies the survival kinetics. There are two aspects that are modified, compared to the untreated samples: one being the greater susceptibility to direct damage and the second, the inability to sustain 
illumination renders the same BL blue and actinic BL doses more effective. From the nearly negligible effect in untreated samples of Figure 2-i, to the lethal doses of 4 and $8 \mathrm{~h}$ (for actinic and blue, respectively) in Figure 2-iv. In all cases, the effect of BL blue light was lower compared to actinic BL light. As far as the disinfection kinetics is concerned, samples that remained more time under the solar light, presented a different response under subsequent light irradiation. In Figure 2-i, the disinfection kinetics were similar until the beginning of the dark storage, while in 2-iv the respective kinetic curves were significantly different. However, Oguma et al. ${ }^{36}$ reported that UVA reactivate cells due to a process called non-concomitant reactivation ${ }^{37}$. This is in variance to our findings (for the applied intensity), suggesting a broader effect on bacteria, and not limited to cyclobutane pyrimidine dimers (CPD) formation, but appointing the contribution of ROS-induced damage as significant.

\subsubsection{Blue and green light effects}

The second experimental part involves subjecting the bacteria in the pre-illuminated samples to exposure under blue or green light. Figure 3 demonstrates the inflicted changes these wavelengths have on bacterial viability. More specifically, in Figure 3-i, the untreated sample is subjected, to illumination by the monochromatic light (for 2, 4 and $8 \mathrm{~h}$ ). In both cases the light effect is not detrimental to the bacterial survival, and only slightly reduces the cell counts of the samples under the blue light.

Similarly, lightly treated samples (1 h of pre-exposure to solar light) do not alter their survival kinetics in great extents, as seen in Figure 3-ii. In this case, the solar pre-treatment for $1 \mathrm{~h}$ modified the kinetics of the blank experiments, and shifted their behavior from growth to survival. However, 2, 4 or $8 \mathrm{~h}$ of exposure to blue or green light do not influence greatly bacterial viability in the short term. On the contrary, $4 \mathrm{~h}$ of blue or green light result in higher cell counts compared to the sample not subjected to the monochromatic light and the beneficial photoreactivating effect was observed.

Two hours of solar pre-illuminated samples were then exposed to monochromatic blue or green light. Blue light in low doses maintains survival but results in noticeable reduction in high doses, whereas green light is detrimental to these samples, stabilizing its effect in high doses. After 4 h, no significant change is observed in the bacterial counts.

Figure 3-iii presents once more the negligible effect of 2-h exposure under monochromatic blue or green light, but $4 \mathrm{~h}$ differ significantly. Although blue light does not affect the bacterial viability, green light seems to reduce the counts by 3 logarithmic units $\left(\log _{10} U\right)$. In long term, the effects are 
reversed. Further irradiation does not inflict more damage due to the green light, but slightly enhances inactivation for the blue light.

Finally, severely damaged cells from solar light demonstrate (figure 3-iv) the most definite alterations in their kinetics among the two colored lamps. Blue light is identified as less inactivating than the green one, and even causes increase of the population in low doses ( $2 \mathrm{~h}$ of exposure). This is in agreement with the photolyase activation spectrum which would repair dimers, but increasing the dose of fluorescent lamp light has little effect on the bacteria exposed in blue light. On the contrary, green light after $8 \mathrm{~h}$ results in total inactivation of more than $2 \log _{10} \mathrm{U}$ of bacteria that remained after 3 hours of solar pretreatment.

\subsubsection{Yellow and visible light lamps’ effects}

The last experimental part involves the exposure of the solar pre-illuminated bacterial samples under lamps emitting yellow light and visible light (indoor light) lamps. Since the two experiments took place in different batches, both control experiments will be presented for reference. Figure 4 demonstrates the main results of the investigation. In Figure 4-i, the effects low intensity yellow and visible light has on non-illuminated bacteria are shown. First of all, there is growth in the dark, similarly to the other two experimental parts. The application of yellow light has no immediate effect; the kinetic curves of 2, 4 or 8-h exposure are very similar, as well as very close to the original, nonirradiated samples. Healthy cells are not affected by the wavelength emitted by the monochromatic lamps, regardless of dose. The kinetics of the bacteria under visible light are close to identical with those under the yellow light ones, being the closest approximation to each other's wavelengths.

Pre-illuminating the samples for $1 \mathrm{~h}$ has almost no effect (Figure 4-ii), when followed by exposure in low yellow light doses. On the other hand, visible light in low doses seems to favor bacterial recovery, causing (slight) increase of the population after 2-h exposure. These results are different in Figure 4iii, which demonstrates the kinetics after $2 \mathrm{~h}$ of solar illumination and exposure to yellow and visible light. The main difference is observed in the bacterial response in high yellow and visible light doses, by prolonging their stay in these conditions; extended illumination time has greater impact on previously more stressed bacterial cells (8-h kinetic curves) and the probability of photoreactivation is reducing significantly. Finally, the response of bacteria that are determined to decay in the dark after some time (figure 4-iv, 3-h treatment), yellow light or visible spectrum irradiation will not change the outcome. 


\subsection{Photoreactivation and the subsequent bacterial survival}

\subsubsection{Post-irradiation dark repair assessment - control experiments}

272

Figure 5 presents the disinfection kinetics, when wastewater samples are exposed to $1000 \mathrm{~W} / \mathrm{m}^{2}$ (global) irradiation intensity. After an initial shoulder ${ }^{30,38,39}$ which presents mild fluctuations due to promoted growth in the supporting matrix, the population is decreasing log-linearly, with $99.99 \%$ inactivation reached in $3.5 \mathrm{~h}$ and total inactivation in $4 \mathrm{~h}$.

Each regrowth/survival curve does not represent the same post-irradiation behavior. The untreated samples present growth directly, the 30 to 90 -min irradiated samples fall between growth and preservation in numbers, and after that point, the kinetics describe a decay. The growth of the untreated sample is normally expected, but the short treated samples (30 min) present an increase, which is supported by the dark repair mechanisms that are enzymatically correcting the DNA lesions $^{40}$, or the respiratory chain ROS scavengers, such as catalase ${ }^{13}$, that suppress the potential indirect damage. As the receiving dose is increasing, the capability of the cells to heal their photoinduced damage is reduced after 30-120 min of treatment. After $120 \mathrm{~min}$, the cells accumulate photoproducts and cell death (PCD) follows ${ }^{41}$.

\subsubsection{Modification of dark repair kinetics: Effect of pre-illumination by fluorescent light}

In Figure 6, the alteration of post-irradiation bacterial kinetics in the dark is presented, according to the degree of pre-treatment with solar light and the lamp that was used in the following period. Figures 6-i) to vi) present the effects of $0,1,2$ or $3 \mathrm{~h}$ illumination prior to exposure to the different light from the fluorescent lamps. Here, the modification of the normal dark repair kinetics by low intensity light is assessed, compared to the dark control.

Firstly, the exposure to low doses of BL blue or actinic BL was found to marginally reduce the bacterial cells, until the application of an 8-h equivalent light dose, which inflicts a $3 \log _{10} \mathrm{U}$ reduction of the population. However, after $24 \mathrm{~h}$ hours from stopping the illumination, the remaining population is nearly equal, for 2-h and 4-h. The only difference is presented in long term, where the 8-h irradiated samples under BL blue remain partly viable, while actinic BL leads to inactivation. This difference is attributed to the emission of the extra wavelength band $(405 \mathrm{~nm})$ in the actinic BL lamp. The wavelengths closer to the UVB region mostly cause DNA damage, and nucleotide excision repair 
to the degree of pretreatment, a corresponding difficulty to repair the damage was observed. Finally, as far the long term dark storage is concerned, the untreated samples presented growth. This ability is disrupted after 1-2 h of solar exposure and diminished after $3 \mathrm{~h}$. The application of the blacklight lamps after the solar light exposure, never favored regrowth (photoreactivation) or survival of the microorganisms, but on the contrary enhanced the continuing inactivating profile inflicted by solar light. This behavior was also enhanced as the blacklight exposure times were increased; high doses induce a higher decrease during dark storage times than lower doses. Actinic BL inflicted more acute inactivation than the respective BL blue light doses. It has been reported that UV/near visible region light exposure can induce the formation of Dewar's isomers on the (6-4) PP dimers of DNA ${ }^{9,40}$. It is then suggested that the further damage inflicted is due to this formation. The aforementioned facts lead to the conclusion that the extent of damages by solar illumination modifies, or predetermines a more vulnerable and non-recurring profile of kinetics, when followed by these light wavelengths.

Concerning the infliction of blue and green light in all the used doses, a similar effect in bacterial kinetics of untreated cells is observed. The initial population is very close to the initial samples. The untreated bacteria are able to continue reproducing in the dark and increase their numbers over $48 \mathrm{~h}$. In contrast, even $2 \mathrm{~h}$ of exposure under blue or green light is enough to disrupt the normal reproductive rates, and lead to slightly decreased population after $48 \mathrm{~h}$. Increasing the exposure times has almost no effect. Although samples that have been illuminated for $1 \mathrm{~h}$ under solar light at 1000 $\mathrm{W} / \mathrm{m}^{2}$ can recover their damage, here all samples that have been exposed to the blue and green lamps are no longer able to express regrowth. In long term, the control sample results in higher population than the other photo-treatment pathways. When 2 hours of treatment were followed by blue or green light, there is noticeable regrowth in the samples that were exposed to green light, indicating the nondetrimental effect of the photoreactivating light. However, the final population has reached its minimum and after $48 \mathrm{~h}$ the bacterial counts are similar, for the same dose of PHR light. This fact suggests that the exposure to these wavelengths has not diminished completely their replicating ability. Finally, compared with the bacterial samples that did not go through blue light exposure, the resulting numbers for bacteria pre-illuminated for $3 \mathrm{~h}$ were higher in all cases, and very close to the population before blue light. It seems that the healthy cells benefited more than damaged ones from this wavelength. On the contrary, only mild (2-h) exposure to green light seems to have a beneficial long term effect; all other doses inflict total inactivation in $24 \mathrm{~h}$ (4-h green light dose) or directly (8-h green light dose). In these wavelengths (among 400-450 nm) Fpg-sensitive modifications occur, which can possibly continue the damages on the genome ${ }^{43}$. That could could possibly explain the dual effect of photo-reactivation in healthy cells or deterioration of the damage, when the repair mechanisms are no longer present. In the case of total inactivation due to green light, there is no regrowth observed in the dark, similarly to the case of the efforts to photo-reactivate totally inactivated bacteria, after $4 \mathrm{~h}$ of solar illumination. 
The last two sub-graphs summarize the results of long term storage of previously illuminated samples by solar light, followed by yellow or visible light. In untreated samples, the dark control samples demonstrate the normal growth kinetics, as well as the samples that went through exposure to the PHR light. Growth was suppressed, compared to the dark control, but in 48 h hours the final population is similar. Visible light has more or less the same effect but a) the recovery in 2 days is higher than the one demonstrated in yellow lamps and b) closer to the untreated samples, when exposure was prolonged. After application of $1 \mathrm{~h}$ solar light followed by PHR yellow or visible light, only small doses of visible light are able to increase the bacterial counts. Another difference in high doses is the relative evolution through the $48 \mathrm{~h}$; when the sample was exposed for $8 \mathrm{~h}$ under yellow light, a temporary decrease was observed, followed by recovery of the numbers in long term. The kinetics are shifted only after the dark storage of 2-h damaged samples. All kinetics are declining in long term. In short term, visible light doses leave bacteria slightly stressed, but the tendency after $48 \mathrm{~h}$ in the dark reveals a minor decrease in the total number of cultivable cells. Compared to the untreated cells (only 1-h of solar illumination), the tendency of dark repair is changed. Finally, heavily damaged bacteria are unable to perform dark repair after their exposure to any dose of yellow or visible light. The reasoning is probably hidden in the wavelengths that can produce singlet oxygen; it has been reported that its production can be initiated with wavelengths as high as $700 \mathrm{~nm}^{44}$. The impact of these wavelengths is demonstrated in long term survival in the dark. In fact, under high doses of visible light exposure, even low intensity ones, after $48 \mathrm{~h}$ of storage there are no longer cultivable bacteria. In both cases the kinetic curves all fall below the dark control experiments.

\subsection{Quantitative and qualitative assessment of photoreactivation after solar disinfection}

\subsubsection{Fluorescent light exposure and modeling of the bacterial response.}

In order to assess the amount of PHR induced and relationship between the doses, the different phases of the bacterial dark storage are divided into $\mathrm{C}_{0}, \mathrm{C}_{24}$ and $\mathrm{C}_{48}$, being the population after solar exposure and fluorescent lamps light, plus 24 and $48 \mathrm{~h}$ of dark storage, respectively. For this analysis, all the data were used, including the semi-hourly measurements not presented before. The total of 216 tests were evaluated to point out the statistical significance of the findings.

The first step was the Pearson test, which reveals the correlation between the parameters under investigation: i) exposure to solar light, ii) exposure to PHR light (dose), iii) $\log C_{0}$, iv) $\log C_{24}$ and v) 
$\log C_{48}$. The results are summarized in Table 3. The independent variables (exposure to solar or PHR 372 light) have no correlation with each other, while solar exposure significantly affects the outcome in 373 short $\left(\log C_{0}\right)$ or long term, having absolute values higher than 0.8 . The negative sign indicates the negative influence of solar light against bacterial survival. Furthermore, the PHR dose is shown as negative but with insignificant correlation. This result is influenced both by the majority of the cases which present further reduction of the bacterial numbers by the PHR light. Exposure to PHR light modifies the relationship between PHR dose and bacterial survival as "mild negative correlation". However, the remaining bacterial populations at the end of each stage (solar and PHR exposure, 1-day dark storage), with the Pearson values being greater than 0.8 , plus indicating the positive influence of the remaining bacteria in their survival, from one day to another.

The outcome of the whole sequence can be expressed by a linear model, taking as independent variables the solar and PHR light doses and the effects summarized in $\log C_{0}, \log C_{24}$ and $\log _{48}$, as defined before. Regression analysis provided three models for the three cases of short or long term survival. The Gauss-Newton algorithm was used for the acquisition of the parameters (max iterations $=200$, tolerance 0.00001 ).

$$
\begin{aligned}
& \log C_{0}=\text { Initial population }-0.00107 * \text { Solar Dose }-0.00108 * \text { PHR Dose } \\
& \log C_{24}=\text { Initial population }-0.00124 * \text { Solar Dose }-0.00134 * \text { PHR Dose } \\
& \log C_{48}=\text { Initial population }-0.00127 * \text { Solar Dose }-0.00179 * \text { PHR Dose }
\end{aligned}
$$
at time $\mathrm{x}$ (initial population for the dark storage period), in CFU/mL, while solar and PHR dose are in $\mathrm{W} / \mathrm{m}^{2}$.

Finally, Figure 7 presents the model vs. the experimental data. The comparison of the theoretical and the experimental $\log \mathrm{C}_{0}, \log \mathrm{C}_{24}$ and $\log \mathrm{C}_{48}$ are presented in Figures $7 \mathrm{a}, 7 \mathrm{~b}$ and $7 \mathrm{c}$ respectively. The assessment indicates a good fit between calculated and experimental values (R-sq: 72-77\%) with the residual errors and R-sq values presented in Table 4. As an assay focusing on correlating the parameters involved, rather than modeling the process, the results are satisfactory. The predictive value of the model is relatively limited, since its main weakness is the non-linear accumulation of photo-damage from hour 4 to hour 8, during the light reactivation process. Nevertheless, this general approach producing these models fits adequately all 6 types of lamps and intensities used in this study. 


\subsubsection{Correlation of bacterial response with the applied PHR light wavelength}

402

403 Although the lamps used in this study cover a significant part of the solar spectrum, the spectrum of 404 each lamp includes a whole wavelength range. Figure 8 presents in the vertical axis the wavelengths, 405 while the horizontal axis is solar (pre)exposure time. For each color, the exposure time to PHR light is noted, followed by the 24 and $48 \mathrm{~h}$ of dark storage. Red stages show populations lower than the previous state, while green refers to higher bacterial population.

408 The BL blue and the actinic BL lamps do not lead to photoreactivation (exception: $2 \mathrm{~h}$ of exposure to actinic BL). This is due to the continuous UV action to the cells, regardless of their previous state of damage. The low PHR rate in the 2-h actinic light dose is due to the extra wavelength in the far UV region. Blue and green lamps present the most cases of PHR, especially in lightly damaged cells. In addition, blue is the only color that demonstrates (long term) PHR in heavily damaged cells (3-h exposure to solar light). This result agrees with the findings of Kumar et al. ${ }^{45}$ for the correlation

414 between blue light and the UVB-induced damages. Yellow light presents long term effects of bacterial 415 increase, regardless of the PHR dose in unharmed cells, but has no actual PHR effect; it probably 416 causes photo-activation of dormant cells. Finally, visible light has similar effect to the yellow light, 417 with lower long-term risk of PHR. Nevertheless, the absence of short or long term reactivation was 418 observed on cells that were treated for more than 3 hours. There is no PHR observed neither during 419 exposure to monochromatic or visible light, nor in the subsequent dark storage time. In contrast with 420 UVC irradiation, where "total inactivation" is observed but often reversible, solar irradiation had a detrimental effect towards photoreactivation, inhibiting the reappearance of cells under light or dark conditions. 
The application of 6 different colors of fluorescent lamps on previously simulated conditions of solar treatment of secondary effluent caused different response, according to the corresponding wavelength. In all cases, however, no regrowth or photoreactivation was observed in totally inactivated samples containing E. coli.

More specifically, UV lamps (BL blue and actinic BL), induce bacterial inactivation, according to the previous damage state of bacteria. The effect was detrimental both in short term, during the 8-h long PHR time, and in long term (permanent effect in 24 and $48 \mathrm{~h}$ of dark storage). Blue and green light were the only ones to cause mild photoreactivation. Partly damaged and heavily damaged bacteria, respectively, demonstrated immediate recovery. In long term, the solar irradiation effects were more visible, for higher CFU concentration, compared to the non-photoreactivated samples. Yellow light has been found to positively affect growth mostly in non-treated cells, causing photo-activation of the cells. The bacterial pre-exposure to solar light followed by yellow light showed continuation of the inactivation effects. The response to visible light resembled the yellow light one, with beneficial photo-activation in relatively healthy cells.

The bacterial response to photoreactivating light correlated with the solar pre-treatment dose, and linear models were proposed to predict the outcome of low exposure to PHR lights ( $\left.\mathrm{R}^{2} \cong 75 \%\right)$. In overall, the risk of photoreactivation is reduced with increased exposure to solar light, regardless of the PHR wavelength and dose. As it appears, contrary to UVC, solar disinfection inflicts damage in various levels and targets, minimizing the bacterial regrowth potentials. A potential regrowth risk could appear only in samples where bacteria able to mend the solar-inflicted lesions, usually having endured under low light doses and not deriving from samples that have undergone extensive illumination.

\section{Acknowledgements}

The authors wish to thank Juan Kiwi for the advice during the review process. Stefanos Giannakis acknowledges the Swiss Agency for Development and Cooperation (SDC) and the Swiss National Foundation for the Research for Development Grant, for the funding through the project "Treatment of the hospital wastewaters in Côte d'Ivoire and in Colombia by advanced oxidation processes” (Project No. 146919). 


\section{References}

458

1. Drinan, J. E., \& Spellman, F. R. (2012). Water and wastewater treatment: A guide for the nonengineering professional: Crc Press.

461 2. Giannakis, S., Vives, F. A. G., Grandjean, D., Magnet, A., De Alencastro, L. F., \& Pulgarin, C. (2015). Effect of Advanced Oxidation Processes on the micropollutants and the effluent organic matter contained in municipal wastewater previously treated by three different secondary methods. Water Res, 84, 295-396.

465 3. Rodríguez-Chueca, J., Ormad, M. P., Mosteo, R., Sarasa, J., \& Ovelleiro, J. L. (2015).

466 Conventional and Advanced Oxidation Processes Used in Disinfection of Treated Urban

467 Wastewater. Water Environment Research, 87(3), 281-288.

468 4. White, G. C. (2010). White's handbook of chlorination and alternative disinfectants: Wiley.

469 5. Hallmich, C., \& Gehr, R. (2010). Effect of pre-and post-UV disinfection conditions on 470 photoreactivation of fecal coliforms in wastewater effluents. Water Res, 44(9), 2885-2893.

471 6. Hijnen, W., Beerendonk, E., \& Medema, G. J. (2006). Inactivation credit of UV radiation for 472 viruses, bacteria and protozoan (oo) cysts in water: a review. Water Res, 40(1), 3-22.

473 7. Nebot Sanz, E., Salcedo Davila, I., Andrade Balao, J. A., \& Quiroga Alonso, J. M. (2007).

474 Modelling of reactivation after UV disinfection: effect of UV-C dose on subsequent photoreactivation 475 and dark repair. Water Res, 41(14), 3141-3151. doi: 10.1016/j.watres.2007.04.008

476 8. Shang, C., Cheung, L. M., Ho, C.-M., \& Zeng, M. (2009). Repression of photoreactivation 477 and dark repair of coliform bacteria by TiO2-modified UV-C disinfection. Applied Catalysis B: 478 Environmental, 89(3), 536-542.

479 9. Pattison, D. I., \& Davies, M. J. (2006). Actions of ultraviolet light on cellular structures. 480 In Cancer: cell structures, carcinogens and genomic instability (pp. 131-157). Birkhäuser Basel.

481 10. Matallana-Surget, S., Villette, C., Intertaglia, L., Joux, F., Bourrain, M., \& Lebaron, P. 482 (2012). Response to UVB radiation and oxidative stress of marine bacteria isolated from South Pacific 483 Ocean and Mediterranean Sea. $J$ Photochem Photobiol B, 117, 254-261. doi: 484 10.1016/j.jphotobiol.2012.09.011

485 11. Storz, G., \& Imlay, J. A. (1999). Oxidative stress. Current opinion in microbiology, 2(2), 188486194.

487 12. Robertson, J., J Robertson, P. K., \& Lawton, L. A. (2005). A comparison of the effectiveness 488 of TiO2photocatalysis and UVA photolysis for the destruction of three pathogenic micro-organisms. 489 Journal of Photochemistry and Photobiology A: Chemistry, 175(1), 51-56.

490 13. Bosshard, F., Bucheli, M., Meur, Y., \& Egli, T. (2010). The respiratory chain is the cell's 491 Achilles' heel during UVA inactivation in Escherichia coli. Microbiology, 156(7), 2006-2015. 

disinfection of drinking water contained in transparent plastic bottles: characterizing the bacterial inactivation process. J Appl Microbiol, 84(6), 1138-1148.

495 15. Neuman, K. C., Chadd, E. H., Liou, G. F., Bergman, K., \& Block, S. M. (1999). Characterization of Photodamage to Escherichia coli in Optical Traps. Biophysical Journal, 77(5), 2856-2863. doi: http://dx.doi.org/10.1016/S0006-3495(99)77117-1 16. McGuigan, K. G., Conroy, R. M., Mosler, H. J., du Preez, M., Ubomba-Jaswa, E., \& Fernandez-Ibanez, P. (2012). Solar water disinfection (SODIS): a review from bench-top to roof-top. J Hazard Mater, 235-236, 29-46. doi: 10.1016/j.jhazmat.2012.07.053

501 17. Fernández Zenoff, V., Siñeriz, F., \& Farías, M. E. (2006). Diverse Responses to UV-B 502 Radiation and Repair Mechanisms of Bacteria Isolated from High-Altitude Aquatic Environments. 503 Applied and Environmental Microbiology, 72(12), 7857-7863. doi: 10.1128/aem.01333-06

504 18. Davies-Colley, R. J., Donnison, A. M., Speed, D. J., Ross, C. M., \& Nagels, J. W. (1999). 505 Inactivation of faecal indicator micro-organisms in waste stabilisation ponds: interactions of environmental factors with sunlight. Water Res, 33(5), 1220-1230. doi: http://dx.doi.org/10.1016/S0043-1354(98)00321-2

508 19. Bohrerova, Z., \& Linden, K. G. (2007). Standardizing photoreactivation: Comparison of 509 DNA photorepair rate in Escherichia coli using four different fluorescent lamps. Water Res, 41(12), $510 \quad 2832-2838$.

511 20. Kashimada, K., Kamiko, N., Yamamoto, K., \& Ohgaki, S. (1996). Assessment of 512 photoreactivation following ultraviolet light disinfection. Water Science and Technology, 33(10), 261513269.

514 21. Vélez-Colmenares, J. J., Acevedo, A., Salcedo, I., \& Nebot, E. (2012). New kinetic model for 515 predicting the photoreactivation of bacteria with sunlight. Journal of Photochemistry and 516 Photobiology B: Biology, 117(0), 278-285. doi: http://dx.doi.org/10.1016/j.jphotobiol.2012.09.005

517 22. Lindenauer, K. G., \& Darby, J. L. (1994). Ultraviolet disinfection of wastewater: effect of 518 dose on subsequent photoreactivation. Water Res, 28(4), 805-817.

519 23. Quek, P. H., \& Hu, J. (2008). Indicators for photoreactivation and dark repair studies 520 following ultraviolet disinfection. Journal of industrial microbiology \& biotechnology, 35(6), 533521541.

522 24. Yoon, C. G., Jung, K.-W., Jang, J.-H., \& Kim, H.-C. (2007). Microorganism repair after UV523 disinfection of secondary-level effluent for agricultural irrigation. Paddy and Water Environment, 524 5(1), 57-62.

525 25. Giannakis, S., Darakas, E., Escalas-Cañellas, A., \& Pulgarin, C. (2015). Solar disinfection 526 modeling and post-irradiation response of Escherichia coli in wastewater. Chemical Engineering 527 Journal, 281, 588-598. 
528 26. Rincón, A.-G., \& Pulgarin, C. (2004a). Bactericidal action of illuminated $\mathrm{TiO}_{2}$ on pure 529 Escherichia coli and natural bacterial consortia: post-irradiation events in the dark and assessment of 530 the effective disinfection time. Applied Catalysis B: Environmental, 49(2), 99-112. doi: 531 10.1016/j.apcatb.2003.11.013

532 27. Giannakis, S., Darakas, E., Escalas-Cañellas, A., \& Pulgarin, C. (2014b). Elucidating 533 bacterial regrowth: Effect of disinfection conditions in dark storage of solar treated secondary 534 effluent. Journal of Photochemistry and Photobiology A: Chemistry, 290(0), 43-53. doi: 535 http://dx.doi.org/10.1016/j.jphotochem.2014.05.016

$53628 . \quad$ Thompson, C. L., \& Sancar, A. (2002). Photolyase/cryptochrome blue-light photoreceptors 537 use photon energy to repair DNA and reset the circadian clock (Vol. 21).

538 29. OECD Guidelines for Testing of Chemicals, Simulation Test-Aerobic Sewage Treatment 539 303A, 1999

540 30. Berney, M., Weilenmann, H. U., Simonetti, A., \& Egli, T. (2006). Efficacy of solar 541 disinfection of Escherichia coli, Shigella flexneri, Salmonella Typhimurium and Vibrio cholerae. $J$ 542 Appl Microbiol, 101(4), 828-836. doi: 10.1111/j.1365-2672.2006.02983.x

543 31. Sciacca, F., Rengifo-Herrera, J. A., Wéthé, J., \& Pulgarin, C. (2011). Solar disinfection of 544 wild Salmonella sp. in natural water with a 18L CPC photoreactor: Detrimental effect of non-sterile 545 storage of treated water. Solar Energy, 85(7), 1399-1408.

546 32. Odonkor, S. T., \& Ampofo, J. K. (2013). Escherichia coli as an indicator of bacteriological 547 quality of water: an overview. Microbiology Research, 4(1), e2.

548 33. Spuhler, D., Andrés Rengifo-Herrera, J., \& Pulgarin, C. (2010). The effect of Fe2+, Fe3+, $549 \mathrm{H} 2 \mathrm{O} 2$ and the photo-Fenton reagent at near neutral $\mathrm{pH}$ on the solar disinfection (SODIS) at low 550 temperatures of water containing Escherichia coli K12. Applied Catalysis B: Environmental, 96(1-2), 551 126-141. doi: 10.1016/j.apcatb.2010.02.010

552 34. Giannakis, S., Darakas, E., Escalas-Cañellas, A., \& Pulgarin, C. (2014a). The antagonistic 553 and synergistic effects of temperature during solar disinfection of synthetic secondary effluent. 554 Journal of Photochemistry and Photobiology A: Chemistry, 280(0), 14-26. doi: 555 http://dx.doi.org/10.1016/j.jphotochem.2014.02.003

$55635 . \quad$ Pigeot-Rémy, S., Simonet, F., Atlan, D., Lazzaroni, J., \& Guillard, C. (2012). Bactericidal 557 efficiency and mode of action: A comparative study of photochemistry and photocatalysis. Water Res, 558 46(10), 3208-3218.

559 36. Oguma, K., Katayama, H., \& Ohgaki, S. (2002). Photoreactivation of Escherichia coli after 560 low-or medium-pressure UV disinfection determined by an endonuclease sensitive site assay. Applied 561 and environmental microbiology, 68(12), 6029-6035.

562 37. Jagger, J. (1981). Near-UV radiation effects on microorganisms. Photochem Photobiol, 34(6), 563 761-768. doi: 10.1111/j.1751-1097.1981.tb09076.x 
564 38. Sinton, L. W., Finlay, R. K., \& Lynch, P. A. (1999). Sunlight inactivation of fecal 565 bacteriophages and bacteria in sewage-polluted seawater. Applied and environmental microbiology, 566 65(8), 3605-3613.

567 39. Giannakis, S., Merino Gamo, A. I., Darakas, E., Escalas-Cañellas, A., \& Pulgarin, C. (2013). 568 Impact of different light intermittence regimes on bacteria during simulated solar treatment of 569 secondary effluent: Implications of the inserted dark periods. Solar Energy, 98, Part C(0), 572-581. 570 doi: http://dx.doi.org/10.1016/j.solener.2013.10.022

571 40. Sinha, R. P., \& Häder, D.-P. (2002). UV-induced DNA damage and repair: a review. 572 Photochemical \& Photobiological Sciences, 1(4), 225-236.

573 41. Rincón, A.-G., \& Pulgarin, C. (2004b). Field solar E. coli inactivation in the absence and 574 presence of TiO2: is UV solar dose an appropriate parameter for standardization of water solar 575 disinfection? Solar Energy, 77(5), 635-648. doi: 10.1016/j.solener.2004.08.002

576 42. Lo, H. L., Nakajima, S., Ma, L., Walter, B., Yasui, A., Ethell, D. W., \& Owen, L. B. (2005). 577 Differential biologic effects of CPD and 6-4PP UV-induced DNA damage on the induction of 578 apoptosis and cell-cycle arrest. BMC cancer, 5(1), 135.

579 43. Kielbassa, C., Roza, L., \& Epe, B. (1997). Wavelength dependence of oxidative DNA 580 damage induced by UV and visible light. Carcinogenesis, 18(4), 811-816.

581 44. Rastogi, R. P., Kumar, A., Tyagi, M. B., \& Sinha, R. P. (2010). Molecular mechanisms of 582 ultraviolet radiation-induced DNA damage and repair. Journal of nucleic acids, 2010.

583 45. Kumar, A., Tyagi, M. B., Singh, N., Tyagi, R., Jha, P. N., Sinha, R. P., \& Häder, D.-P. 584 (2003). Role of white light in reversing UV-B-mediated effects in the N2-fixing cyanobacterium 585 Anabaena BT2. Journal of Photochemistry and Photobiology B: Biology, 71(1-3), 35-42. doi: 586 http://dx.doi.org/10.1016/j.jphotobiol.2003.07.002 

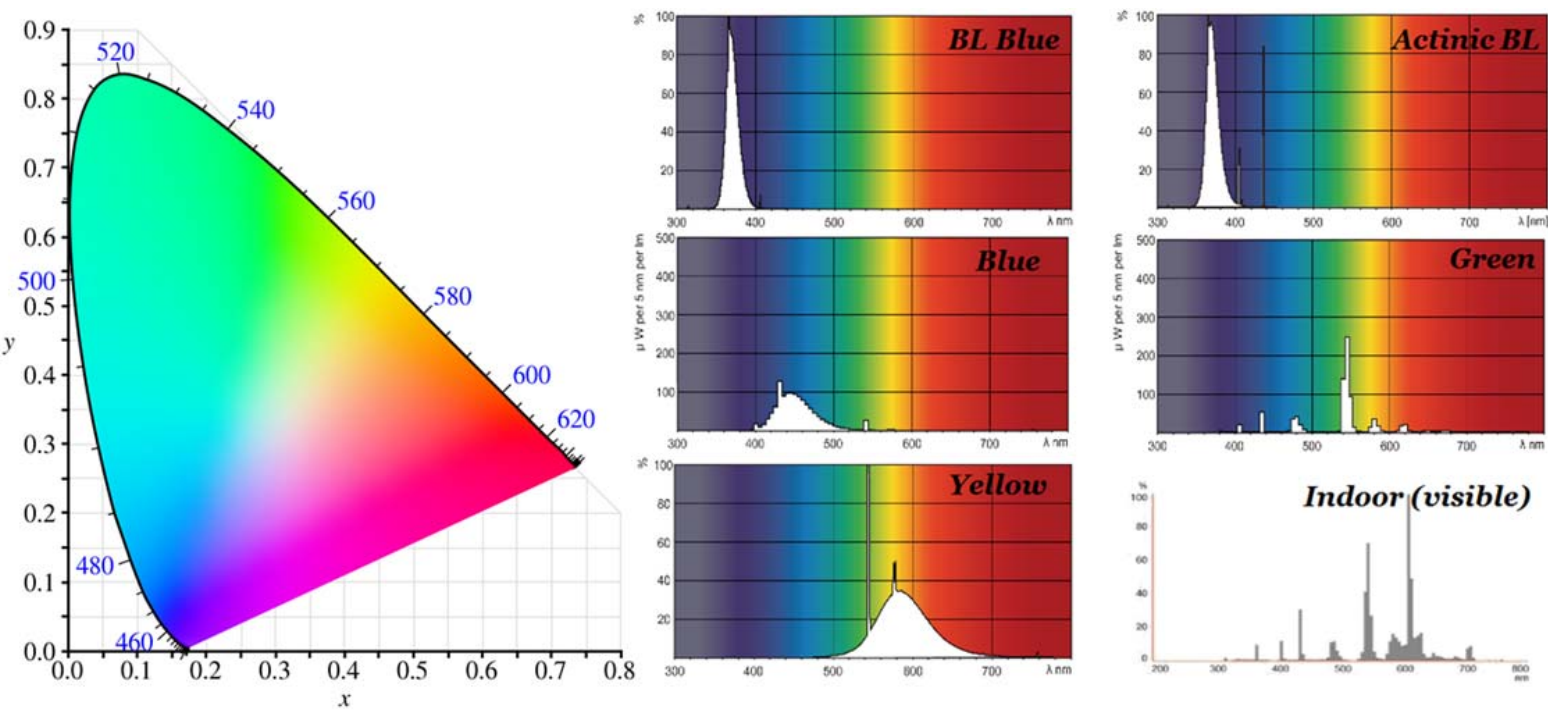

Figure 1 - International Commission on Illumination (CIE) color space chromaticity diagram and emission spectra of the fluorescent lamps
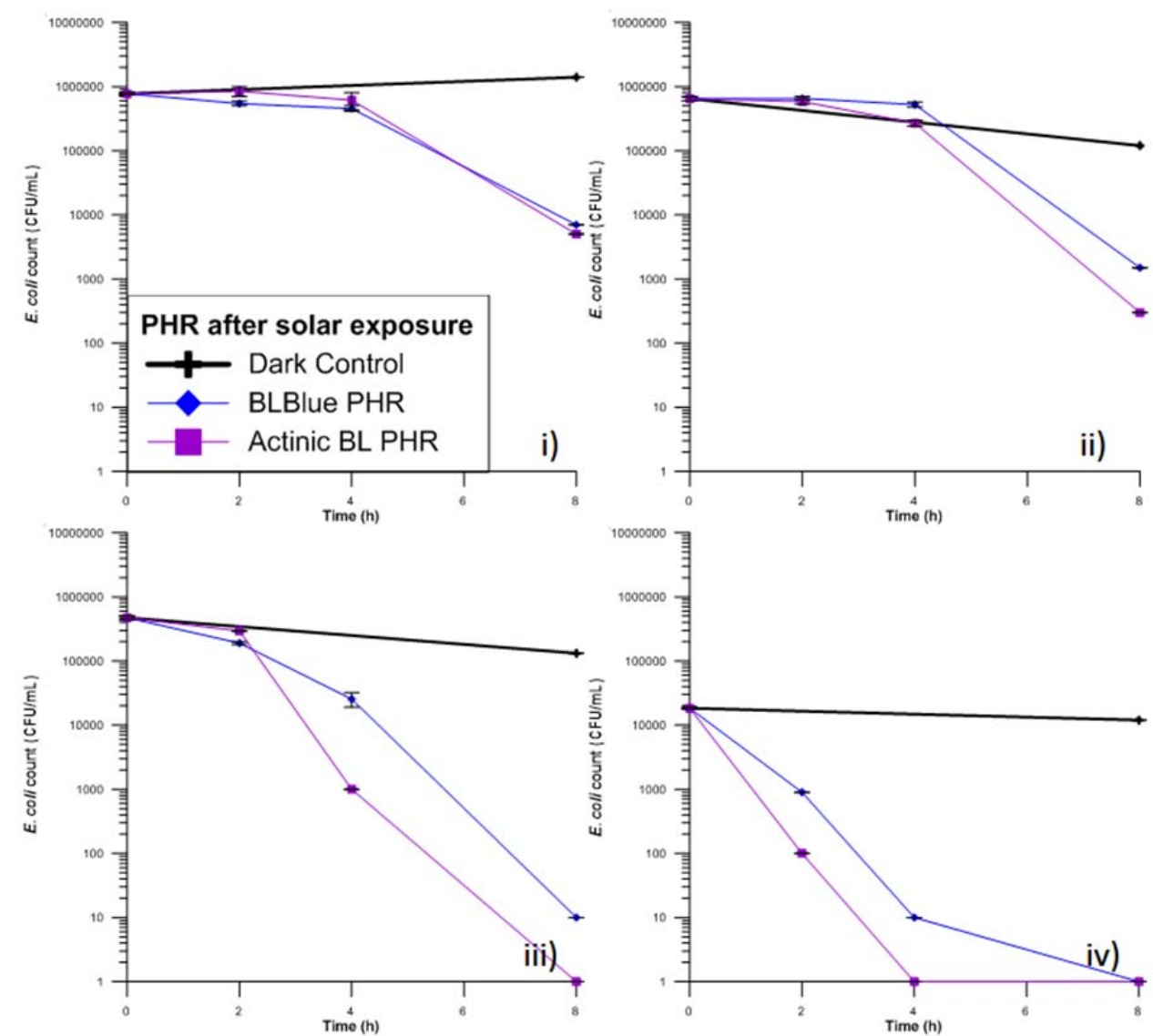

Figure 2 - Results of the exposure of wastewater in fluorescent lamps: BL blue and actinic BL. i) exposure without solar pre-treatment. ii) after $1 \mathrm{~h}$ solar pre-treatment. iii) after $2 \mathrm{~h}$ solar pre- 
treatment. iv) after 3 h solar pre-treatment. The experimental values acquired are connected by a line for better visualization of the results.
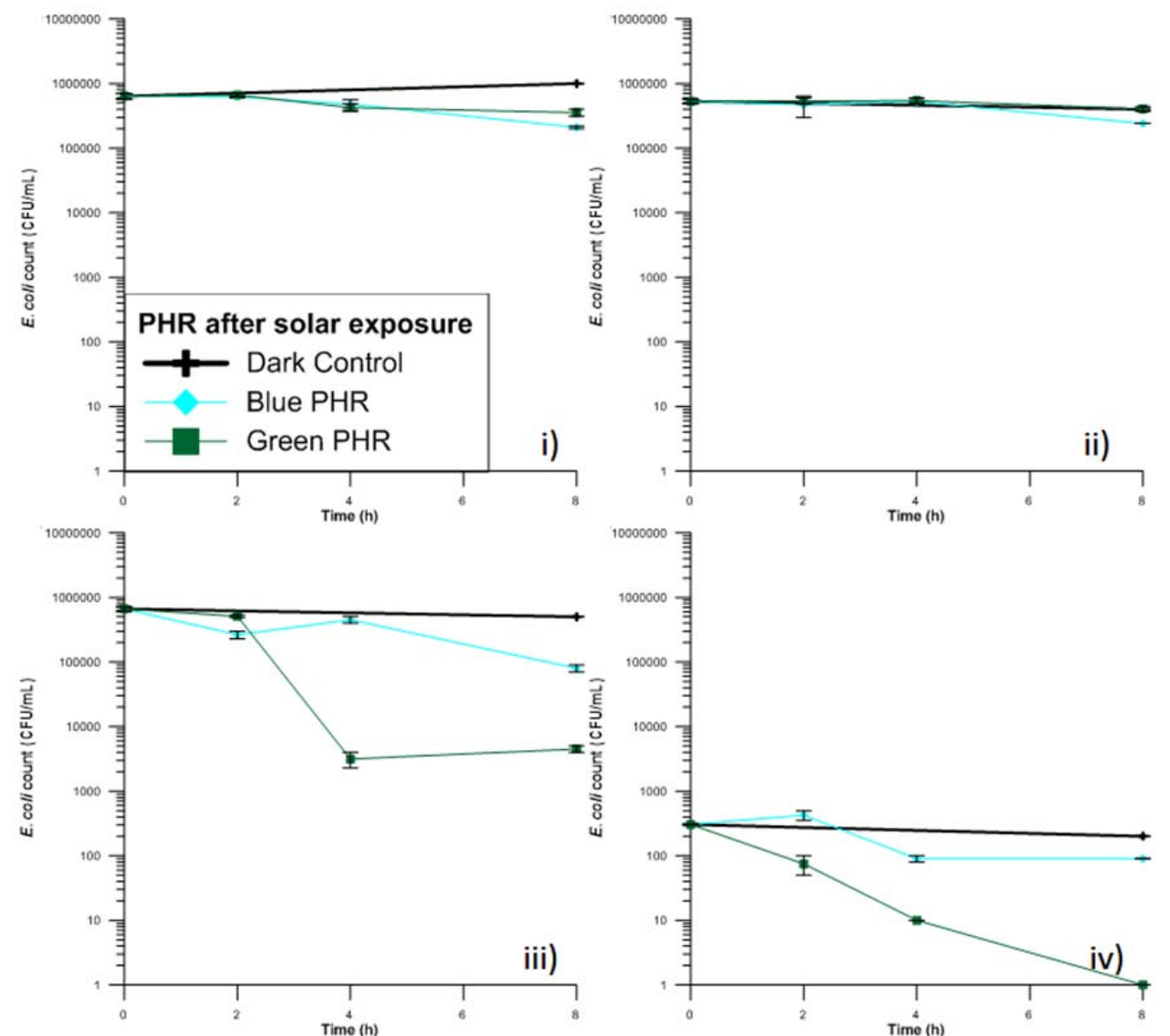

597

Figure 3 - Results of the exposure of wastewater in fluorescent lamps: Blue and green light. i) without solar pre-treatment. ii) after $1 \mathrm{~h}$ solar pre-treatment. iii) after $2 \mathrm{~h}$ solar pre-treatment. iv) PHR after 3 h solar pre-treatment. The experimental values acquired are connected by a line for better visualization of the results. 

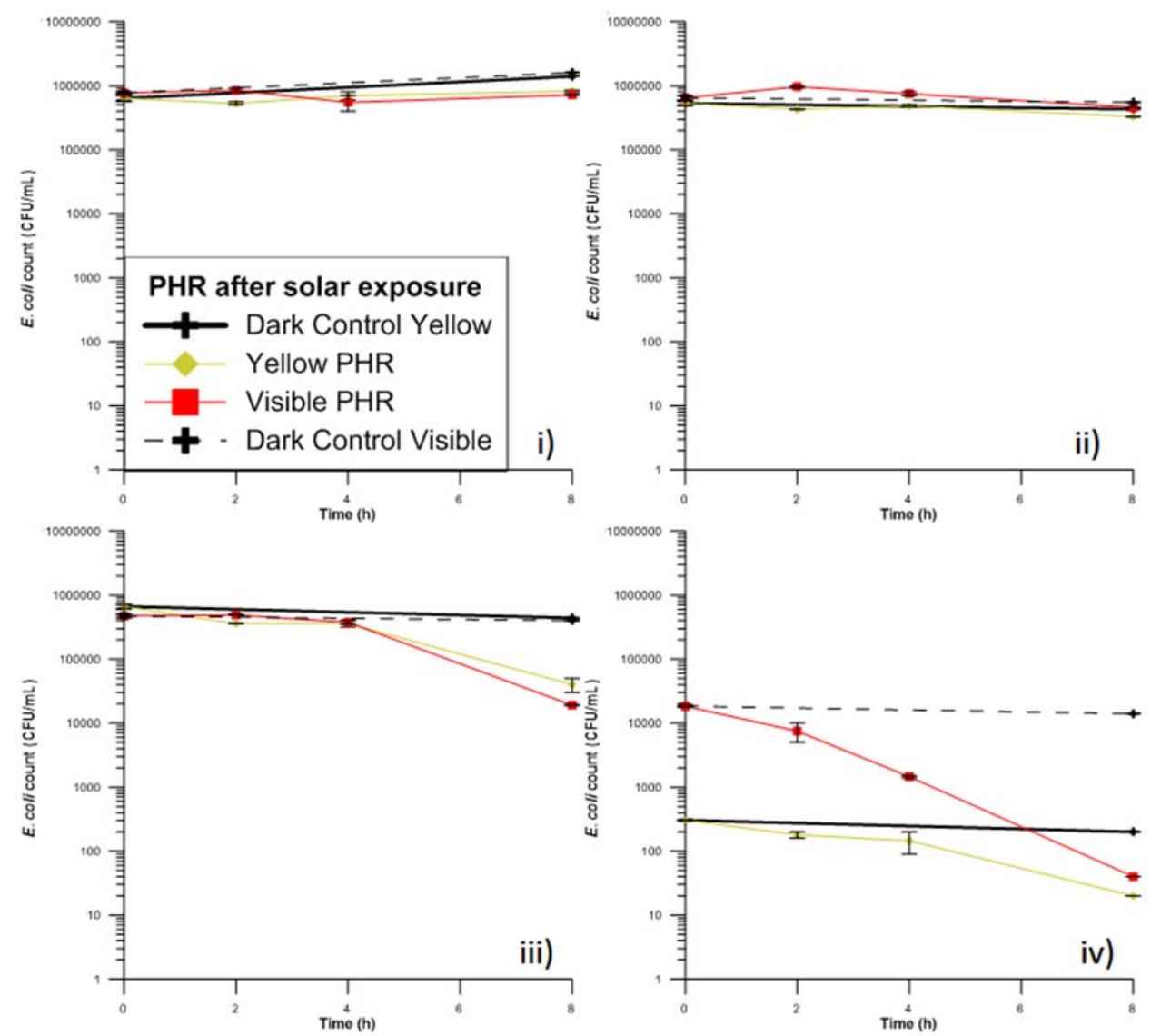

Figure 4 - Results of the exposure of wastewater in fluorescent lamps: Yellow and visible light. i) without solar pre-treatment. ii) after $1 \mathrm{~h}$ solar pre-treatment. iii) after $2 \mathrm{~h}$ solar pre-treatment. iv) after 3 h solar pre-treatment. The experimental values acquired are connected by a line for better
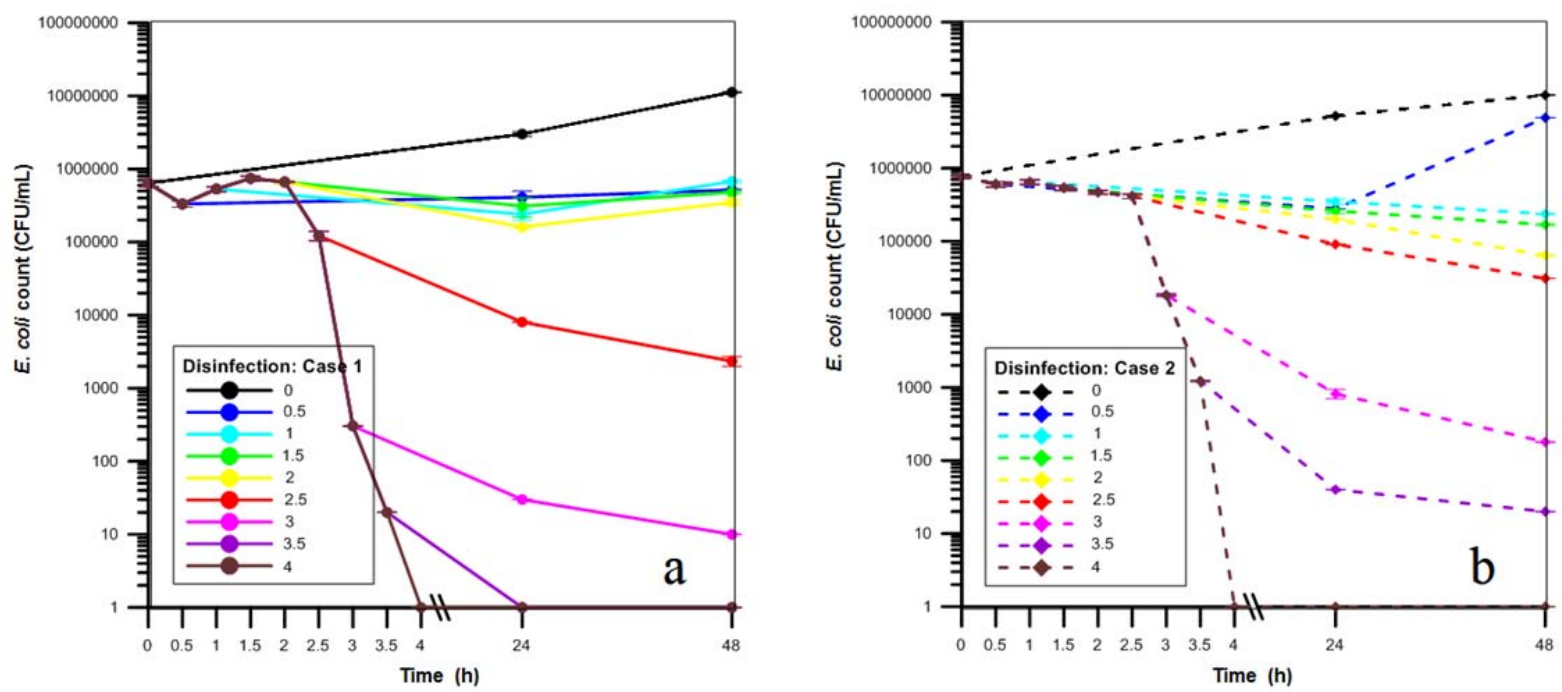
Figure 5 - Blank experiments: dark repair after solar disinfection of wastewater. Results of the 48-h long dark storage of solar treated wastewater, for the two different batches. a) Case 1. b) Case 2. The experimental values acquired are connected by a line for better visualization of the results.

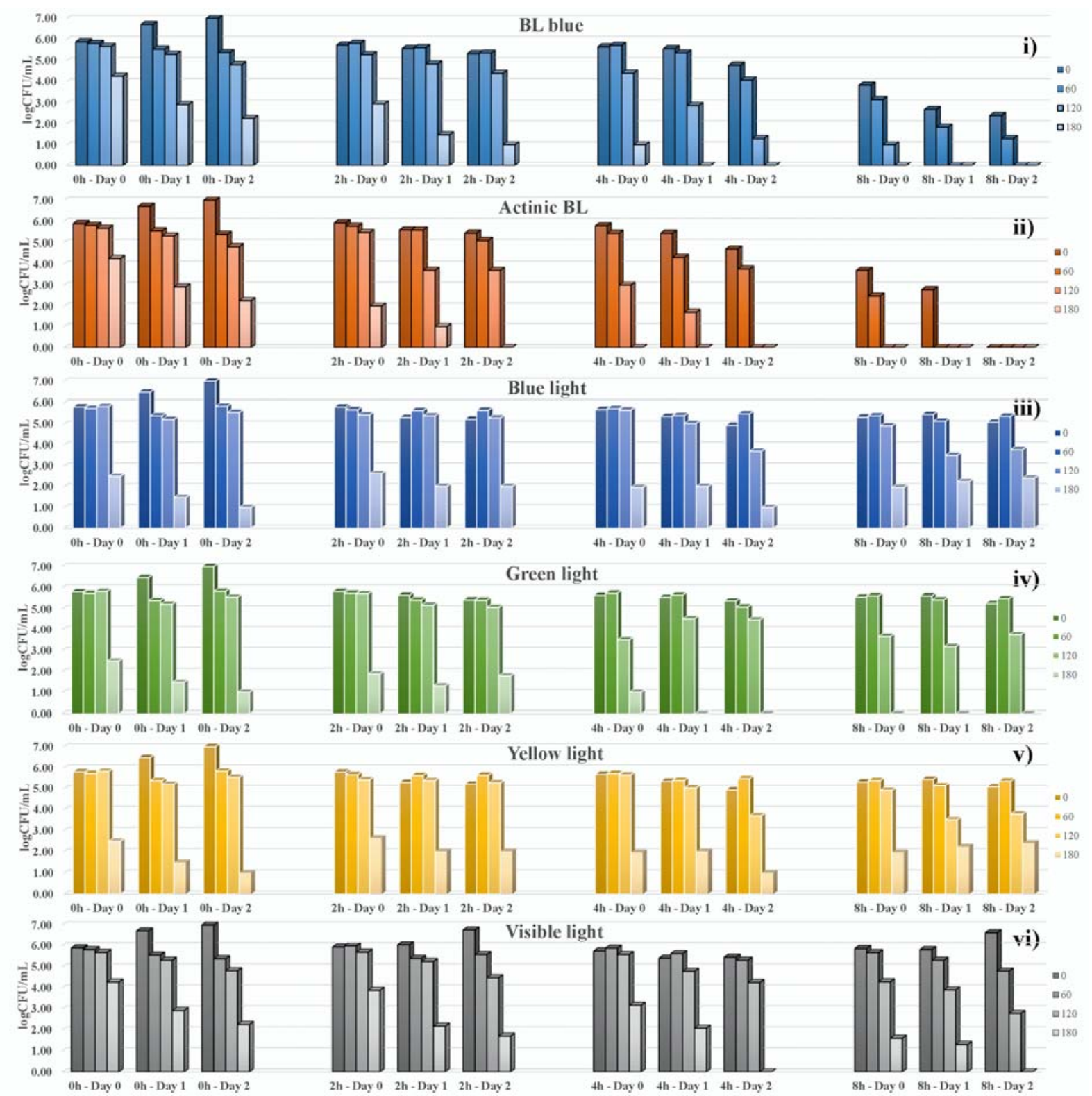

Figure 6 - Results of the 48-h long dark storage of 0 to 3-h solar treated samples, after 0, 2, 4 and $8 \mathrm{~h}$ of fluorescent light: i) BL blue, ii) actinic BL, iii) blue, iv) green, v) yellow and vi) visible light. 

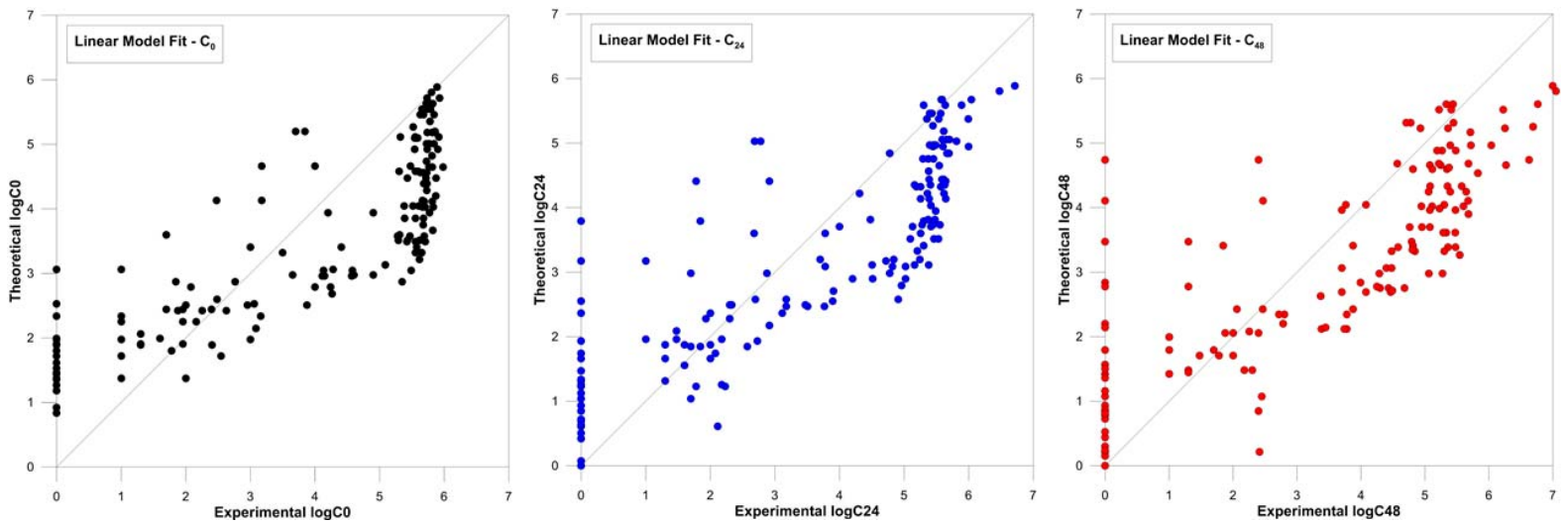

Figure 7 - Quantitative assessment of PHR - Goodness of fit: Experimental vs. Theoretical (Model) data. i) $C_{0}$. ii) $C_{24}$. iii) $C_{48}$.

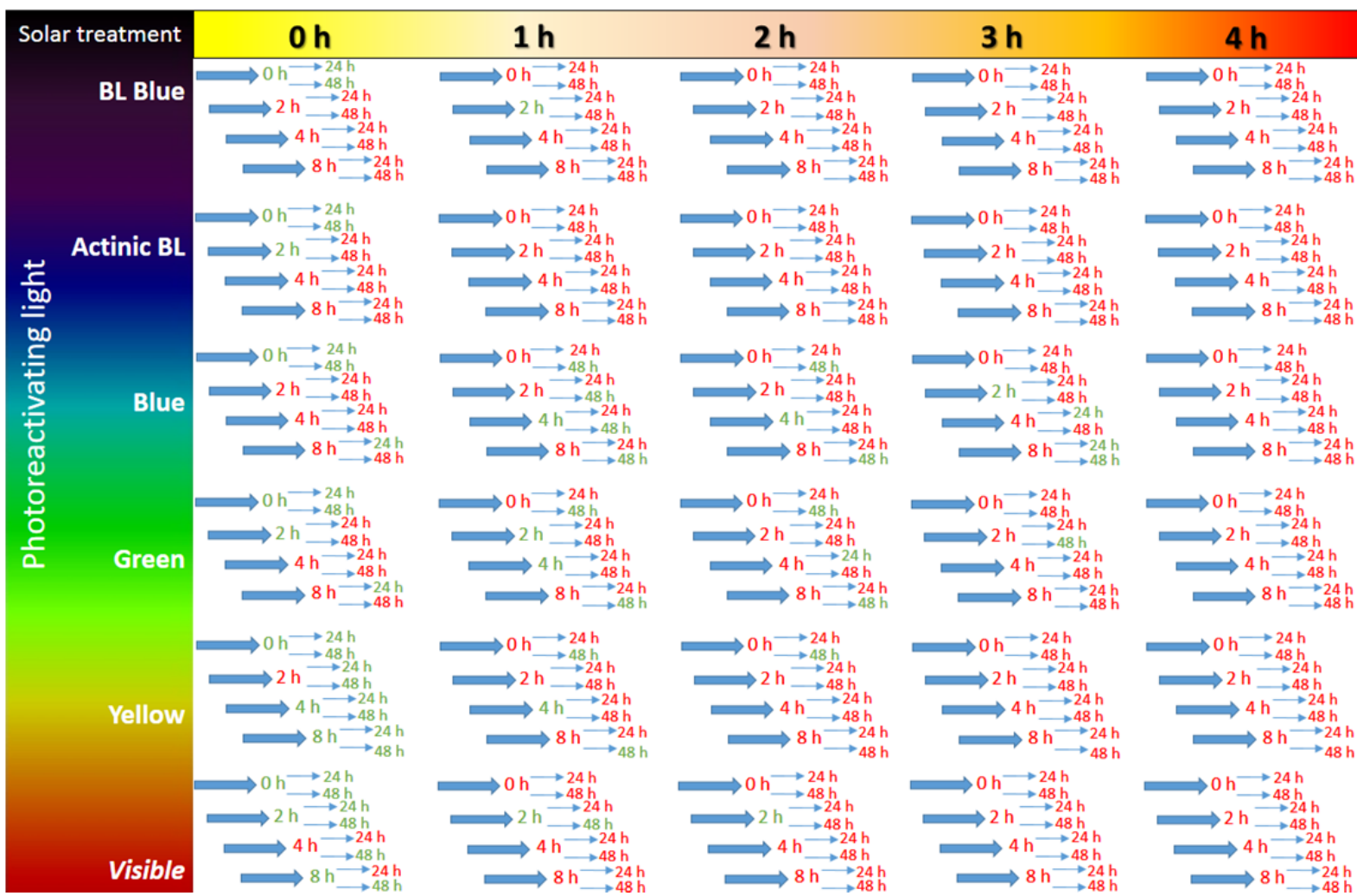

Figure 8 - Overview of the PHR and DR results, grouped per solar pre-treatment dose, PHR dose and dark storage time. For each fluorescent color lamp, the exposure time to light is noted. The indicated red stages are the ones resulting in populations lower than the previous state, while green indicates higher numbers. 


\begin{tabular}{|cc|}
\hline Chemicals Concentration (mg/L) \\
\hline & \\
\hline Peptone & 160 \\
\hline Meat extract & 110 \\
\hline Urea & 30 \\
\hline $\mathrm{K}_{2} \mathrm{HPO}_{4}$ & 28 \\
\hline $\mathrm{NaCl}$ & 7 \\
\hline $\mathrm{CaCl}_{2} \cdot 2 \mathrm{H}_{2} \mathrm{O}$ & 4 \\
\hline $\mathrm{MSSO}_{4} \cdot 7 \mathrm{H}_{2} \mathrm{O}$ & 2 \\
\hline
\end{tabular}

628

629

630

\begin{tabular}{|c|c|c|c|c|c|c|c|}
\hline $\begin{array}{c}\text { Fluorescent } \\
\text { Lamp }\end{array}$ & $\begin{array}{c}\text { Color } \\
\text { Designation }\end{array}$ & Code & $\begin{array}{c}\text { Coordinat } \\
\text { e X }\end{array}$ & $\begin{array}{c}\text { Coordinat } \\
\text { e Y }\end{array}$ & UVA & $\begin{array}{l}\text { UVB/ } \\
\text { UVA }\end{array}$ & $\begin{array}{c}\text { Provider } \\
\text { Model }\end{array}$ \\
\hline $\begin{array}{c}\text { Blacklight } \\
\text { blue }\end{array}$ & Blacklight Blue & 108 & - & - & $3.9 \mathrm{~W}$ & $0.20 \%$ & $\begin{array}{c}\text { Philips } \\
\text { TL-D 18W }\end{array}$ \\
\hline $\begin{array}{c}\text { Actinic } \\
\text { blacklight }\end{array}$ & Actinic & 10 & 222 & 210 & $5.0 \mathrm{~W}$ & $0.20 \%$ & $\begin{array}{c}\text { Philips } \\
\text { TL-D 18W }\end{array}$ \\
\hline Blue light & Blue & 180 & 157 & 75 & & & $\begin{array}{c}\text { Philips } \\
\text { TL-D 18W }\end{array}$ \\
\hline Green light & Green & 170 & 246 & 606 & & & $\begin{array}{c}\text { Philips } \\
\text { TL-D 18W }\end{array}$ \\
\hline Yellow light & Yellow & 160 & 495 & 477 & & & $\begin{array}{c}\text { Philips } \\
\text { TL-D 18W }\end{array}$ \\
\hline Visible light & $\begin{array}{c}\text { LUMILUX } \\
\text { Cool White } \\
2700 \mathrm{~K}\end{array}$ & 840 & 0.38 & 0.38 & $\begin{array}{c}\text { UVA } \\
<150 \\
\mathrm{~mW} / \mathrm{kl} \\
\mathrm{m}\end{array}$ & $0.13 \%$ & $\begin{array}{c}\text { OSRAM } \\
827 \\
\text { Lumilux } \\
\text { Interna }\end{array}$ \\
\hline
\end{tabular}

Table 2 - Color distribution of the employed fluorescent lamps 


\begin{tabular}{|c|c|c|c|c|}
\hline & Solar Dose & PHR Dose & $\log C_{\mathbf{0}}$ & $\log _{24}$ \\
\hline PHR dose & 0 & \multicolumn{3}{l|}{} \\
\hline $\log C_{\mathbf{0}}$ & -0.823 & -0.278 & & \\
\hline $\log C_{\mathbf{2 4}}$ & -0.848 & -0.259 & 0.961 & 0.972 \\
\hline $\log C_{\mathbf{4 8}}$ & -0.827 & -0.29 & 0.923 & \\
\hline
\end{tabular}

634

635

Table 4 - Models evaluation and goodness of fit

\begin{tabular}{|cccccc|}
\hline LogC & \multicolumn{2}{c}{ LogC $_{\mathbf{2 4}}$} & \multicolumn{2}{c|}{ LogC $_{\mathbf{4 8}}$} \\
\hline $\mathbf{R S E}$ & 0.7238 & $\mathbf{R S E}$ & 0.7789 & $\mathbf{R S E}$ & 0.8265 \\
\hline $\mathbf{R}^{2}$ & 0.7369 & $\mathbf{R}^{2}$ & 0.774 & $\mathbf{R}^{2}$ & 0.7588 \\
\hline $\mathbf{R}^{2}$-(adj) & 0.7356 & $\mathbf{R}^{2}$-(adj) & 0.773 & $\mathbf{R}^{2}$-(adj) & 0.7577 \\
\hline $\mathbf{F}$ & 599.2 & $\mathbf{F}$ & 733 & $\mathbf{F}$ & 673.3 \\
\hline p-value & $<2.2 \mathrm{e}-16$ & $\mathbf{p}$-value & $<2.2 \mathrm{e}-16$ & $\mathbf{p}$-value & $<2.2 \mathrm{e}-16$ \\
\hline
\end{tabular}

637

638 


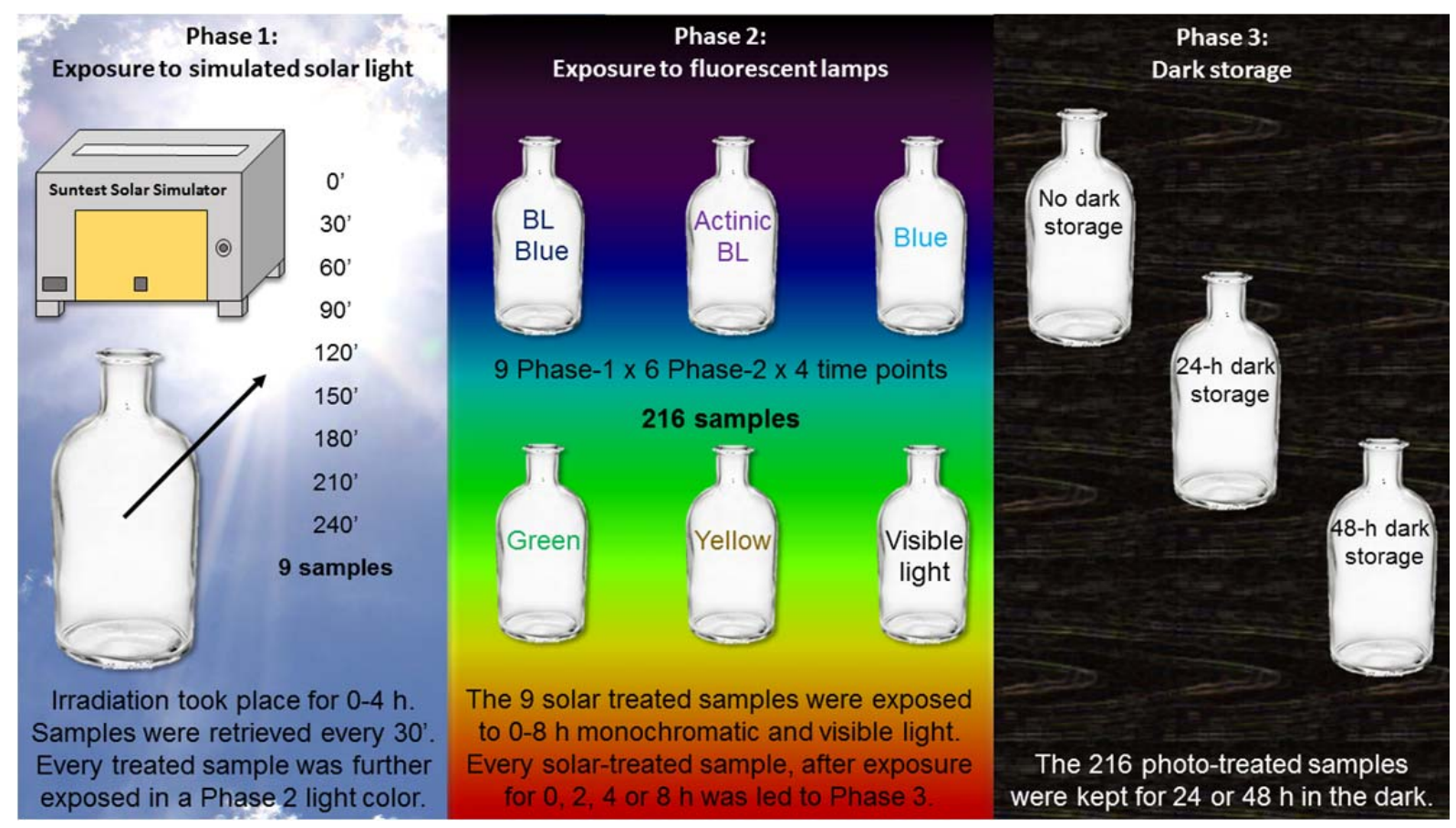



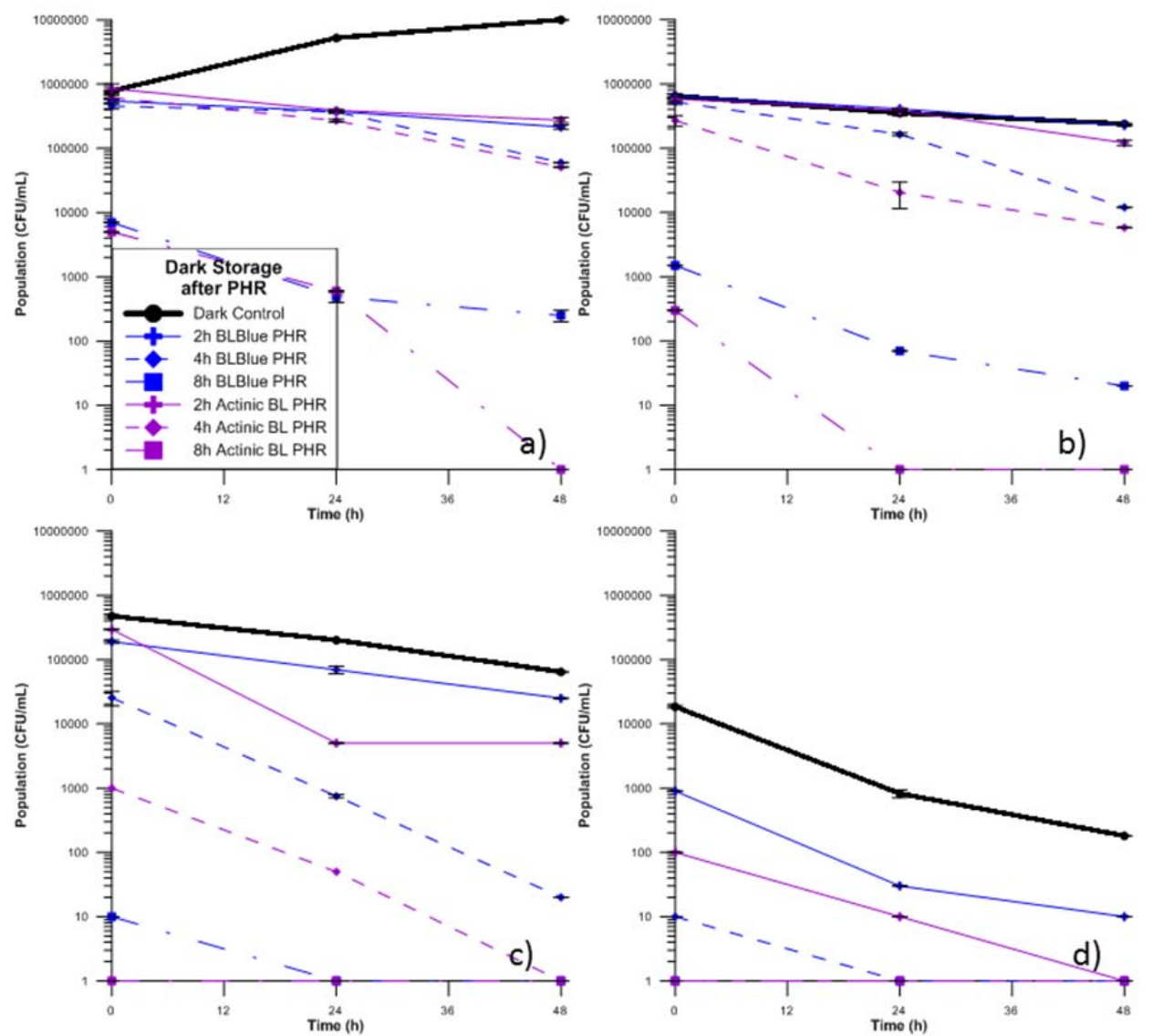

643

644 Supplementary Figure 2 - Results of the dark storage of samples after solar exposure and BL Blue or 645 actinic BL light. i) without solar pre-treatment. ii) after $1 \mathrm{~h}$ solar pre-treatment. iii) after $2 \mathrm{~h}$ solar 646 pre-treatment. iv) PHR after 3 h solar pre-treatment. The experimental values acquired are connected 647 by a line for better visualization of the results. 

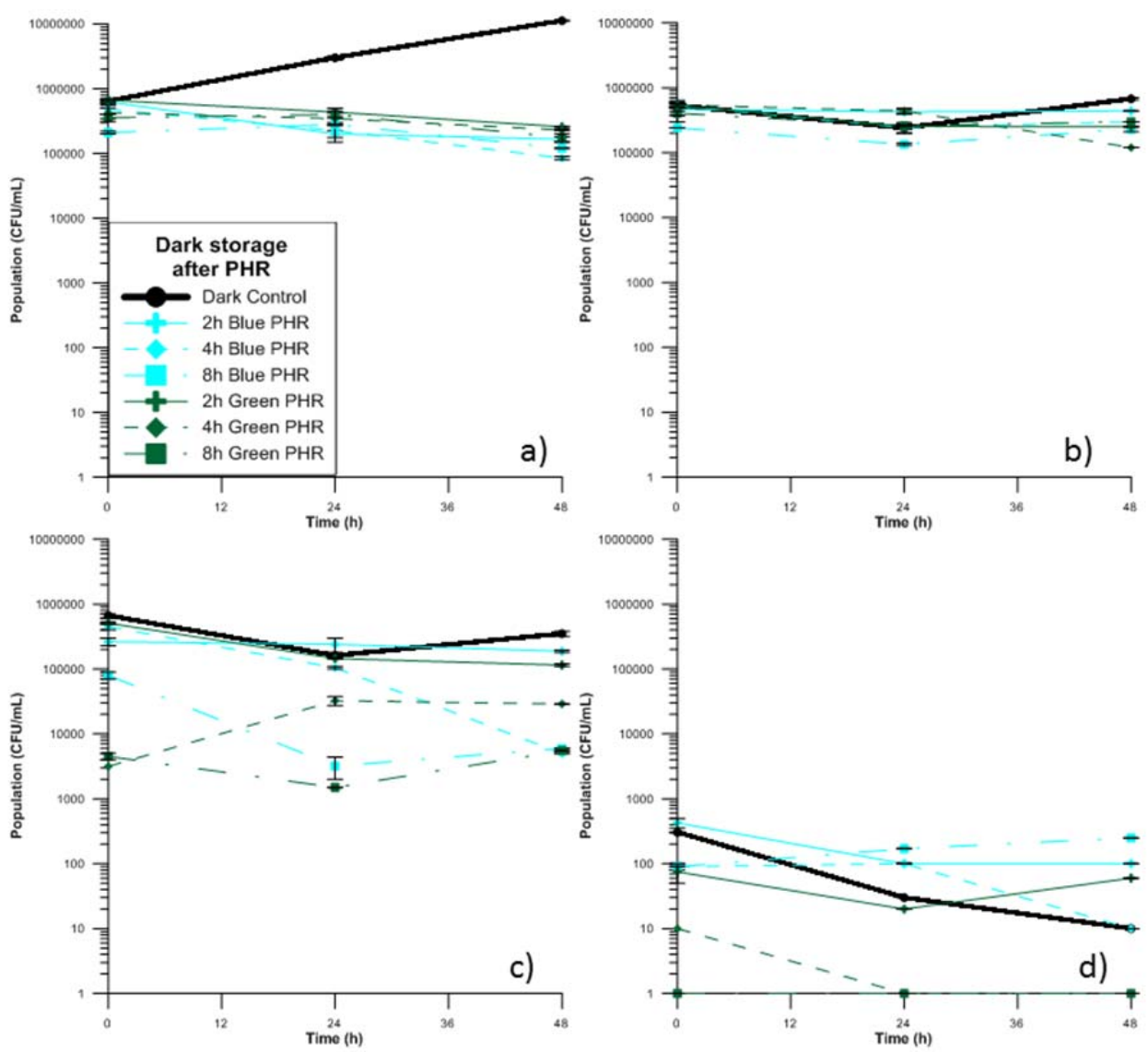

650 Supplementary Figure 3 - Results of the dark storage of samples after solar exposure and blue or 651 green light. i) without solar pre-treatment. ii) after $1 \mathrm{~h}$ solar pre-treatment. iii) after $2 \mathrm{~h}$ solar pre652 treatment. iv) PHR after 3 h solar pre-treatment. The experimental values acquired are connected by 653 a line for better visualization of the results. 

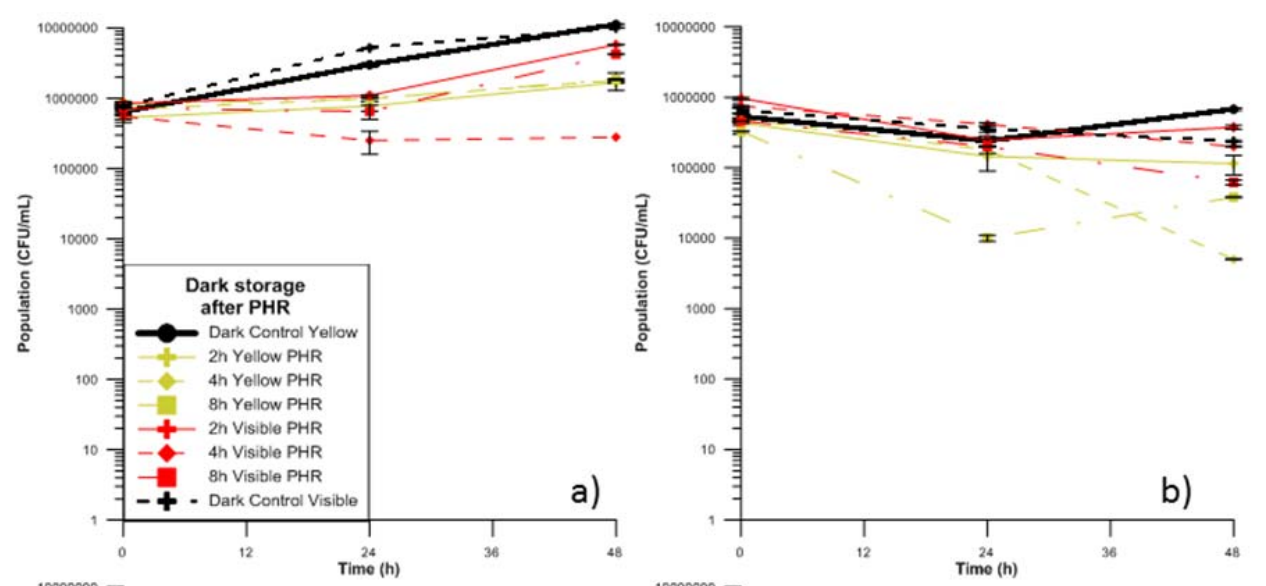

655
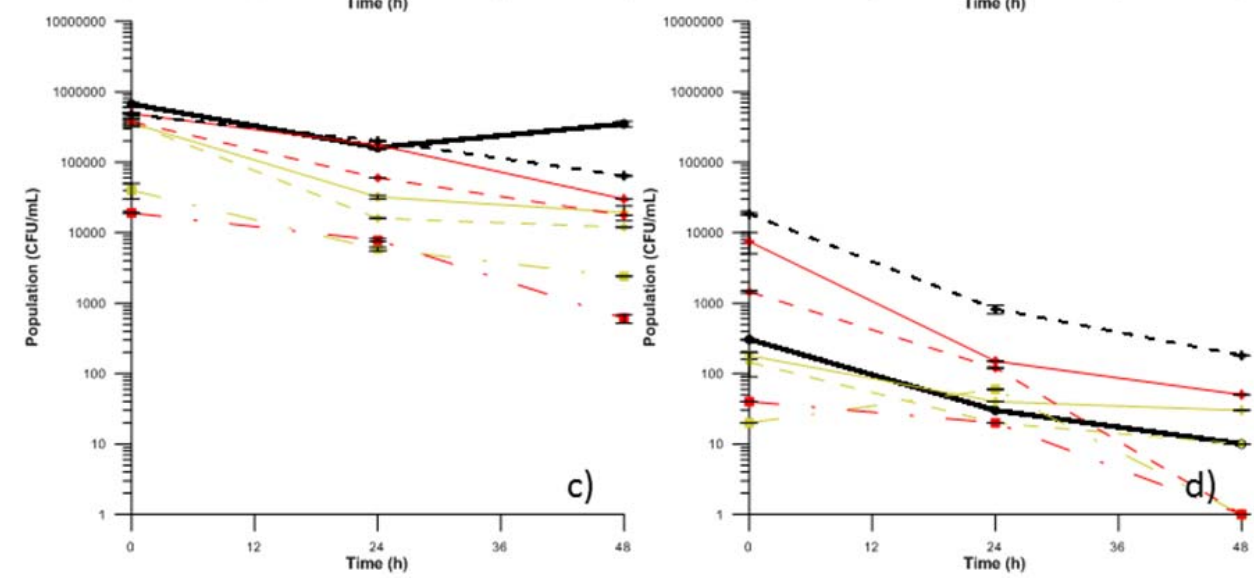

656 Supplementary Figure 4 - Results of the dark storage of samples after solar exposure and yellow or 657 indoor light. i) without solar pre-treatment. ii) after $1 \mathrm{~h}$ solar pre-treatment. iii) after $2 \mathrm{~h}$ solar pre658 treatment. iv) PHR after $3 \mathrm{~h}$ solar pre-treatment. The experimental values acquired are connected by 659 a line for better visualization of the results.

660 